\title{
STUDI DAYA DUKUNG EKOWISATA AIR TERJUN WIYONO DI TAMAN HUTAN RAYA WAN ABDUL RACHMAN PROVINSI LAMPUNG
}

\section{(THE STUDY OF CARRYING CAPACITY OF WIYONO WATERFALL ECOTOURISM IN WAN ABDUL RACHMAN GREAT FOREST PARK LAMPUNG PROVINCE)}

\author{
Rahmat Walimbo, Christine Wulandari, dan Rusita \\ Jurusan Kehutanan Fakultas Pertanian Universitas lampung \\ Jl. Soemantri Brojonegoro No. 1 Bandar Lampung \\ E-mail: Rahmatwalimbo@ymail.com \\ Phone : 085789134806
}

\begin{abstract}
ABSTRAK
Taman Hutan Raya Wan Abdul Rachman (Tahura WAR) merupakan Kawasan Pelestarian Alam (KPA) di Provinsi Lampung. Hutan tersebut memiliki kekayaan alam hayati dan non hayati dan dapat dikembangkan untuk kegiatan ekowisata. Salah satu lokasi di kawasan Tahura WAR yang dapat dijadikan ekowisata adalah Air Terjun Wiyono. Selama ini, kawasan Air Terjun Wiyono digunakan untuk kegiatan piknik dan berkemah. Sebagai salah satu kawasan yang berpotensi untuk dikembangkan kegiatan ekowisata, maka perlu dilakukan studi mengenai daya dukung untuk mengetahui kemampuan kawasan dalam menerima sejumlah wisatawan dengan tetap menjaga kualitas lingkungan Air Terjun Wiyono. Penelitian dilaksanakan pada bulan Desember 2015 dengan tujuan mengetahui daya dukung kawasan, potensi flora dan fauna, serta persepsi wisatawan dan masyarakat lokal. Metode penelitian adalah perhitungan berdasarkan rumus Cifuentes (1992) terdiri dari daya dukung fisik, daya dukung ekologis, dan daya dukung riil. Daya dukung fisik dilakukan untuk memperoleh kepuasan wisatawan. Daya dukung ekologis dilakukan untuk menjaga keseimbangan ekosistem. Daya dukung riil dilakukan untuk menjaga kenyamanan dan keselamatan wisatawan. Pegumpulan data dilakukan melalui survei lapangan, kuesioner, dan wawancara. Hasil penelitian menyatakan bahwa daya dukung fisik sebesar 759 orang/hari untuk piknik dan 122 orang/hari untuk berkemah, daya dukung ekologis sebesar 248 orang/hari untuk piknik dan 165 orang/hari untuk berkemah, dan daya dukung riil sebesar 51 orang/hari untuk piknik dan 9 orang/hari untuk berkemah. Keanekaragaman flora di sepanjang jalur ekowisata masuk dalam katagori baik dengan jumlah 28 spesies dan keanekaragaman fauna masuk dalam katagori sangat baik dengan jumlah 23 spesies. Persepsi wisatawan dan masyarakat sepenuhnya mendukung dilakukannya pengembangan ekowisata.
\end{abstract}

Kata kunci: Air Terjun Wiyono, daya dukung, ekowisata

\section{ABSTRACT}

Wan Abdul Rachman (WAR) Great Forest Park is a conservation area in Lampung Province. It has good natural biological and non biological and also can be developed for ecotourism activity. One of objects in WAR Great Forest Park can be used as ecotourism is Wiyono Waterfall. During this time, the waterfall area used for picnic and camping activity. As one of areas with potential to develop ecotourism, it is necessary to study about the carrying capacity area to know ability in receiving tourists while maintaining environment quality in Wiyono Waterfall ecotourism area. This research was conducted in Desember 2015 to determine carrying capacity, flora and fauna potential as well as tourists and local 
communities perception. The method was based on the Cifuentes (1992) formula consists of physical carrying capacity, ecological carrying capacity, and real carrying capacity. The physical carrying capacity was implemented to obtain the tourists saticfaction. The ecological carrying capacity was implemented to maintain the ecosystem balance. The real carrying capacity was implemented to maintain the comfort and safety of tourists. The data was collected by field survey, questionnaires, and interviews method. The result showed that the physical carrying capacity by 759 people/day for picnic and 122 people/day for camping, ecological carrying capacity by 248 people/day for picnic and 165 people/day for camping, and real carrying capacity by 51 people/day for picnic and 9 people/day for camping. The biodiversity flora was included good category with 28 species and fauna was very good category with 23 species. The tourists and communities perception supported fully the development of ecotourism.

Keywords : carrying capacity, ecotourism, Wiyono Waterfall

\section{PENDAHULUAN}

\section{Latar Belakang}

Taman Hutan Raya (Tahura) merupakan salah satu Kawasan Pelestarian Alam (KPA) yang dimanfaatkan untuk kepentingan penelitian, ilmu pengetahuan, pendidikan, menunjang budidaya, budaya, rekreasi, dan pariwisata (Undang-Undang Nomor 5 tahun 1990). Salah satu bentuk pariwisata yang dapat dikembangkan di Tahura adalah ekowisata. Tahura Wan Abdul Rachman (WAR) Provinsi Lampung merupakan Tahura yang ada di Provinsi Lampung.

Salah satu kawasan Tahura WAR yang dapat dijadikan obyek ekowisata adalah Air Terjun Wiyono, terletak di Gunung Betung Register 19, Desa Wiyono Kecamatan Gedong Tataan Kabupaten Pesawaran yang memiliki potensi ekowisata berupa air terjun, bukit-bukit sebagai keindahan panorama alam, dan keanekaragaman flora dan fauna sebagai daya tarik ekowisata tersebut. Bentuk kegiatan yang dapat dilakukan oleh wisatawan di kawasan Air Terjun Wiyono adalah kegiatan berkemah dan piknik, sehingga dalam pemanfaatannya perlu memperhatikan kondisi biofisik lingkungan agar tetap terjaga. Untuk menjaga kelestarian di kawasan Tahura WAR, maka kegiatan wisata harus memperhatikan daya dukung kawasan dalam menerima sejumlah wisatawan agar tidak menimbulkan dampak negatif terhadap kondisi biofisik lingkungan.

Berdasarkan hasil penelitian yang telah dilakukan Affandi pada tahun 2004 menyatakan bahwa daya dukung lingkungan untuk berkemah di lokasi Air Terjun Wiyono melebihi batas maksimum pengunjung yaitu daya dukung fisik kelebihan jumlah pengunjung sebesar 59 orang dari batas maksimum sebesar 54 orang. Kemudian daya dukung ekologis untuk berkemah telah kelebihan jumlah pengunjung sebesar 55 orang dari batas maksimum sebesar 58 orang. Perhitungan kembali terhadap daya dukung kawasan ekowisata Air Terjun Wiyono perlu dilakukan agar tidak menimbulkan dampak negatif terhadap kondisi lingkungan di kawasan tersebut.

\section{Tujuan Penelitian}

Tujuan penelitian ini yaitu sebagai berikut.

1. Mengetahui daya dukung lingkungan meliputi daya dukung fisik, daya dukung ekologis, dan daya dukung riil.

2. Mengetahui potensi flora dan fauna di sepanjang jalur ekowisata.

3. Mengetahui persepsi wisatawan dan masyarakat lokal tentang pengembangan ekowisata Air Terjun Wiyono Tahura WAR Provinsi Lampung. 


\section{METODE PENELITIAN}

Penelitian dilaksanakan di kawasan ekowisata Air Terjun Wiyono Register 19 Gunung Betung Tahura WAR Desa Wiyono Kecamatan Gedong Tataan, Kabupaten Pesawaran, Provinsi Lampung pada bulan Desember 2015.

\section{Daya dukung fisik}

Perhitungan daya dukung fisik dilakukan untuk mengetahui jumlah maksimal wisatawan secara fisik sehingga akan diketahui ambang batas jumlah maksimum wisatawan per rotasi kunjungan. Apabila hal tersebut melampaui dari batas normal, maka akan mengurangi kenyamanan dan kepuasan wisatawan (Lucyanti, 2013). Adapun metode yang digunakan untuk mengetahui daya dukung fisik ekowisata Air Terjun Wiyono menggunakan metode Cifuentes (1992) dengan rumus sebagai berikut (Fandeli, 2002).

$$
\mathrm{PCC}=\mathrm{Ax} \underset{\mathrm{B}}{\frac{1}{\mathrm{~N}}} \times \mathrm{Rf}
$$

Keterangan:

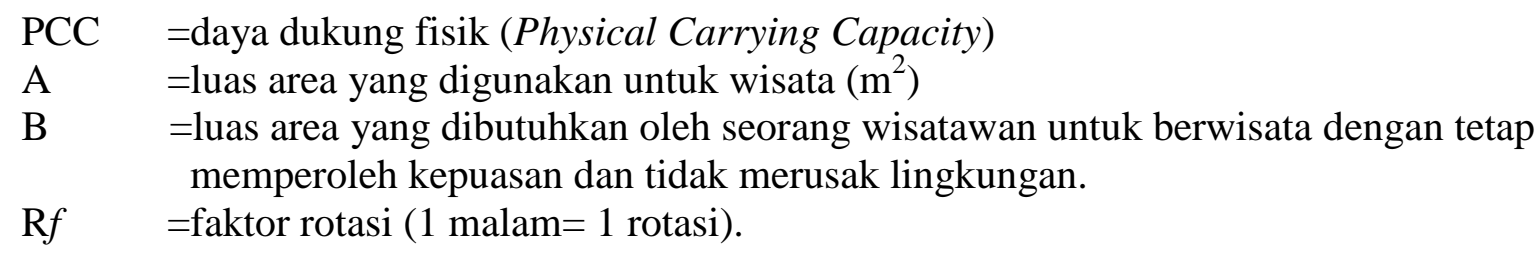

Nilai PCC merupakan nilai dasar yang digunakan untuk menghitung daya dukung ekowisata berikutnya. Nilai PCC digunakan untuk menghitung nilai daya dukung riil yang dibatasi faktor biofisik lingkungan berdasarkan pengamatan di lapangan.

\section{Daya dukung ekologis}

Perhitungan terhadap daya dukung ekologis Air Terjun Wiyono memperhatikan kondisi biofisik lingkungan dan dapat dilakukan dengan tujuan menjaga keseimbangan ekosistem dan kualitas ekowisata di kawasan tersebut. Penurunan kualitas ekowisata akan menyebabkan penurunan daya tarik ekowisata yang berdampak pada penurunan jumlah pengunjung dan pendapatan dari sektor tersebut (Affandy, 2004). Adapun metode untuk mengetahui daya dukung ekologis menggunakan rumus sebagai berikut (Douglass, 1975).

$$
\mathrm{AR}=\frac{\mathrm{DxA}}{\mathrm{CDxTFx} 43.560}
$$

Keterangan:

AR = Kebutuhan area minimal untuk kegiatan wisata tertentu.

$\mathrm{D} \quad=$ rata-rata jumlah pengunjung pertahun

A $\quad=$ kebutuhan area wisata tertentu $\left(907\right.$ Feet $\left.^{2}\right)$

$\mathrm{CD}=$ kapasitas hari pemakaian (dalam waktu 1 tahun)

$\mathrm{TF}=$ Faktor pemulihan $(\mathrm{Kemah}=1.0$ dan Piknik $=1.5)$

$43.560=$ Konstanta.

Perhitungan dilakukan dengan tujuan menjaga keseimbangan ekosistem dan kualitas ekowisata di kawasan tersebut. Penurunan kualitas ekowisata akan menyebabkan penurunan daya tarik ekowisata yang berdampak pada penurunan jumlah pengunjung dan pendapatan dari sektor tersebut. 


\section{Daya dukung riil}

Perhitungan daya dukung riil dilakukan dengan memperhatikan faktor -faktor biofisik sebagai faktor koreksi atau pembatas dengan tujuan menjaga kenyamanan dan keselamatan wisatawan, namun tetap memperhatikan kondisi biofisik lingkungan. Adapun metode yang digunakan untuk mengetahui daya dukung riil menggunakan rumus cifuentes (1992) sebagai berikut.

$$
\mathrm{RCC}=\mathrm{PCC} \times \frac{100-\mathrm{Cf}_{1}}{100} \times \frac{100-\mathrm{Cf}_{2}}{100} \times \frac{100-\mathrm{Cf}_{3}}{100} \underline{\text { dimana } \mathrm{Cf}}=\frac{\mathrm{Mt}_{1}}{\mathrm{Mt}_{2}} \times 100
$$

Keterangan :

$$
\begin{aligned}
& \mathrm{RCC}=\text { daya dukung riil atau real carrying capacity } \quad \mathrm{Mt}_{1} \quad=\text { batas besaran variabel } \\
& \mathrm{Cf}=\text { faktor koreksi } \quad \mathrm{Mt}_{2} \quad \text { = batas variabel total }
\end{aligned}
$$

Faktor-faktor biofisik yang diidentifikasikan sebagai faktor pembatas atau faktor koreksi dalam perhitungan daya dukung riil yaitu curah hujan $\left(\mathrm{Cf}_{1}\right)$, diversitas flora $\left(\mathrm{Cf}_{2}\right)$, dan diversitas fauna $\left(\mathrm{Cf}_{3}\right)$. Menurut Sustri (2009) menyatakan bahwa perhitungan curah hujan didasarkan pada Indeks Curah Hujan selama 10 tahun terakhir dengan membandingkan bulan basah dan bulan kering. Sedangkan perhitungan diversitas flora dan fauna dihitung menggunakan Indeks Diversitas Simpson (IDS) dengan rumus sebagai berikut.

$$
\text { IDS }=1-\lambda \quad \operatorname{dimana} \lambda=\frac{\sum \mathrm{ni}(\mathrm{ni}-1)}{\mathrm{n}(\mathrm{n}-1)}
$$

Keterangan:

ni $\quad$ jumlah individu jenis ke-i $\quad n \quad$ = jumlah individu semua jenis

\section{Potensi flora}

Pengumpulan data potensi flora menggunakan metode titik pusat kuadran (point centered quarter method) di jalur ekowisata Air Terjun Wiyono. Jarak titik sampel dengan sampel lain adalah 100 meter. Pohon yang dicatat adalah nama jenis, famili, diameter batang, tinggi pohon dan daya tarik atau ciri khas yang dimiliki. Adapun kriteria kualitas keanekaragaman pohon yang dikemukakan oleh Fandeli (2000) dapat dilihat pada Tabel 1.

Tabel 1. Kriteria kualitas keanekaragaman flora.

\begin{tabular}{cll}
\hline Skala & \multicolumn{1}{c}{ Jumlah Jenis } & \multicolumn{1}{c}{ Arti } \\
\hline 1 & Terdapat $\leq 5$ jenis tumbuhan & Buruk \\
2 & Terdapat 6--10 jenis tumbuhan & Agak Buruk \\
3 & Terdapat $11--20$ jenis tumbuhan & Sedang \\
4 & Terdapat $21--30$ jenis tumbuhan & Baik \\
5 & Terdapat $\geq 31$ jenis tumbuhan & Sangat Baik \\
\hline
\end{tabular}

\section{Potensi fauna}

Pengumpulan data potensi fauna menggunakan metode eksplorasi yaitu mencatat setiap jenis satwa liar yang dilihat bersamaan dengan pencatatan data potensi flora di sepanjang jalur ekowisata. Data potensi fauna yang diambil meliputi nama jenis dan ciri khas yang dimiliki (bentuk atau warna bulu yang menarik). Adapun kriteria kualitas keanekaragaman fauna yang dikemukakan oleh Fandeli (2000) dapat dilihat pada Tabel 2. 
Tabel 2. Kriteria kualitas keanekaragaman fauna.

\begin{tabular}{cll}
\hline Skala & \multicolumn{1}{c}{ Jumlah Jenis } & \multicolumn{1}{c}{ Arti } \\
\hline 1 & Terdapat 1--2 jenis fauna & Buruk \\
2 & Terdapat 3--5 jenis fauna & Agak Buruk \\
3 & Terdapat 6--10 jenis fauna & Sedang \\
4 & Terdapat $11--15$ jenis fauna & Baik \\
5 & Terdapat $\geq 16$ jenis fauna & Sangat Baik \\
\hline
\end{tabular}

\section{Persepsi wisatawan dan masyarakat}

Data mengenai persepsi wisatawan dan masyarakat dilakukan dengan cara wawancara langsung berdasarkan kuisioner yang telah disediakan. Data mengenai persepsi wisatawan meliputi profil responden (umur, jenis kelamin, pendidikan, daerah asal), tujuan wisatawan, luas area yang dibutuhkan untuk berwisata, dan persepsi terhadap kawasan ekowisata Air Terjun Wiyono. Jumlah Pengunjung wisata di Air Terjun Wiyono tahun 2015 berdasarkan wawancara dengan pengelola adalah 6.050 pengunjung. Selanjutnya data mengenai persepsi masyarakat meliputi profil responden dan persepsi terhadap kawasan ekowisata Air Terjun Wiyono. Populasi yang diambil yaitu masyarakat Desa Wiyono dengan jumlah 1826 Kepala Keluarga (Direktorat Jenderal Pemberdayaan Masyarakat dan Desa, 2014). Banyaknya sampel responden ditentukan dengan formula Slovin (Sevilla,2007) sebagai berikut:

$\mathrm{n}=\frac{\mathrm{N}}{1+\mathrm{Ne}^{2}}$

Keterangan:
n : Ukuran sampel
1 : Bilangan konstan
$\mathrm{N} \quad$ : Ukuran populasi
e $\quad$ : Batas eror $(\mathrm{e}=15 \%)$

Berdasarkan rumus tersebut diperoleh jumlah responden wisatawan dan masyarakat masing-masing sebanyak 44 responden.

\section{HASIL DAN PEMBAHASAN}

\section{Daya dukung fisik}

Kebutuhan areal wisata di kawasan ekowisata Air Terjun Wiyono merupakan hasil pengukuran dengan menggunakan Geografic Positioning System (GPS) kemudian diproses menggunakan aplikasi interpretasi citra sehingga dapat diketahui luas area yang dapat dijadikan wisata yaitu berkemah, seperti pada Tabel 3 .

Tabel 3. Kebutuhan areal wisata di kawasan ekowisata Air Terjun Wiyono.

\begin{tabular}{llccccc}
\hline \multirow{2}{*}{ No } & \multirow{2}{*}{ Lokasi } & $\begin{array}{c}\text { Luas } \\
\left(\mathbf{m}^{2}\right)\end{array}$ & & \multicolumn{2}{c}{$\begin{array}{c}\text { Luas area yang dibutuhkan } \\
\text { wisatawan untuk berwisata } \\
\left(\mathbf{m}^{2} / \text { /orang) }\right.\end{array}$} & \multicolumn{2}{c}{$\begin{array}{c}\text { Faktor rotasi } \\
(\mathbf{R f})\end{array}$} \\
\cline { 3 - 7 } & & 3.363 & Piknik & Kemah & Piknik & Kemah \\
\hline 1 & Air Terjun Atas & 10,68 & 33,16 & 2 & 1 \\
2 & Air Terjun Bawah & 688,566 & & & & 1 \\
\hline
\end{tabular}

Sumber : Data Primer (2016). 
Daya dukung fisik areal wisata Air Terjun Wiyono terbagi kedalam Air Terjun Atas dan Air Terjun Bawah. Air Terjun Atas memiliki luas $3.363 \mathrm{~m}^{2}$ dan Air Terjun Bawah memiliki luas $688,566 \mathrm{~m}^{2}$. Berdasarkan hasil wawancara kepada wisatawan, luas rata-rata area yang dibutuhkan wisatawan untuk berwisata dengan tetap memperoleh kepuasan dan tidak merusak lingkungan yaitu $10,68 \mathrm{~m}^{2} /$ orang untuk piknik dan $33,16 \mathrm{~m}^{2} /$ orang untuk berkemah. Kemudian faktor rotasi untuk aktivitas piknik sebesar 2 diperoleh dari penggunaan wisata dalam sehari selama 8 jam dengan rincian waktu masing-masing 4 jam/rotasi kunjungan di waktu pagi dan sore hari, sedangkan faktor rotasi satu malam untuk aktivitas berkemah sebesar 1 diperoleh dari penggunaan kegiatan wisata oleh wisatawan untuk ber-kemah dan bermalam selama \pm 24 jam.

Berdasarkan hasil perhitungan daya dukung fisik kawasan, maka dapat diketahui daya dukung fisik areal wisata Air Terjun Wiyono yaitu Air Terjun Wiyono Atas memiliki daya dukung fisik untuk piknik dan berkemah masing-masing sebesar 630 orang dan 102 orang. Air Terjun Wiyono Bawah memiliki daya dukung fisik untuk piknik dan berkemah masingmasing sebesar 129 orang dan 20 orang. Jumlah total wisatawan sesuai dengan daya dukung fisik Air Terjun Wiyono dalam satu rotasi kunjungan adalah 759 orang untuk berpiknik dan 122 orang untuk berkemah. Data mengenai daya dukung fisik ekowisata Air Terjun Wiyono dapat dilihat pada Tabel 4.

Tabel 4. Daya dukung fisik areal wisata Air Terjun Wiyono.

\begin{tabular}{|c|c|c|c|c|c|c|c|}
\hline \multirow[t]{2}{*}{ No } & \multirow[t]{2}{*}{ Lokasi } & \multirow{2}{*}{$\begin{array}{c}\text { Luas } \\
\left(\mathbf{m}^{2}\right)\end{array}$} & \multicolumn{2}{|c|}{$\begin{array}{l}\text { Daya Dukung Fisik } \\
\text { (orang/hari) }\end{array}$} & \multirow{2}{*}{$\begin{array}{c}\text { Jumlah } \\
\text { Wisatawan } \\
\text { (orang/hari) }\end{array}$} & \multicolumn{2}{|c|}{$\begin{array}{c}\text { Kelebihan Wisatawan } \\
\text { (orang/hari) }\end{array}$} \\
\hline & & & Piknik & Kemah & & Piknik & Kemah \\
\hline 1 & $\begin{array}{l}\text { Air Terjun } \\
\text { Atas }\end{array}$ & 3.363 & 630 & 102 & \multirow{2}{*}{18} & $612^{*}$ & $84 *$ \\
\hline 2 & $\begin{array}{l}\text { Air Terjun } \\
\text { Bawah }\end{array}$ & 688,566 & 129 & 20 & & $111^{*}$ & $2^{*}$ \\
\hline & Total & 4.052 & 759 & 122 & 18 & $723^{*}$ & $86^{*}$ \\
\hline
\end{tabular}

Keterangan : (*) : Jumlah wisatawan belum melebihi daya dukung fisik

Sumber : Data Primer (2016).

Berdasarkan Tabel 4, diperoleh data dari pengelola tiket masuk wisata Air Terjun Wiyono dalam satu hari (satu rotasi kunjungan) adalah 18 orang. Nilai tersebut merupakan nilai pengunjung aktual saat ini berdasarkan tiket masuk sehingga diketahui rata-rata wisatawan dalam satu hari atau satu rotasi kunjungan.

Areal wisata untuk aktivitas piknik dan berkemah di Air Terjun Wiyono belum melewati dari batas maksimal daya dukung fisik. Hal ini memiliki arti bahwa wisatawan dalam melakukan aktivitas piknik dan berkemah masih merasakan kenyamanan dan kepuasan berwisata di kawasan tersebut. Berdasarkan hal tersebut, pengelola masih dapat mengoptimalkan wisatawan yang datang sesuai nilai daya dukung fisik sehingga dapat meningkatkan perekonomian setempat.

\section{Daya Dukung Ekologis}

Daya dukung ekologis merupakan kemampuan suatu kawasan untuk menampung sejumlah wisatawan dengan memperhitungkan faktor pemulihan suatu kawasan. Perhitungan ini sangat penting dilakukan dengan tujuan untuk menghindari kerusakan lingkungan akibat adanya aktivitas wisata yang dilakukan di kawasan ekowisata Air Terjun Wiyono. Pemanfaatan areal wisata dari adanya aktivitas wisata di kawasan tersebut dapat dilihat pada Tabel 5. 
Tabel 5. Pemanfaatan areal wisata di Air Terjun Wiyono.

\begin{tabular}{cccccc}
\hline $\begin{array}{c}\text { Waktu/Cd } \\
\text { (hari/tahun) }\end{array}$ & $\begin{array}{c}\text { Wisatawan/D } \\
\text { (orang/tahun) }\end{array}$ & $\begin{array}{c}\text { Luas berwisata Douglass } \\
\text { (feet2/orang) }\end{array}$ & \multicolumn{2}{c}{ TF } \\
\hline 96 & 6.050 & 907 & 1.5 & 1 \\
\hline
\end{tabular}

Sumber : Data Primer (2016).

Berdasarkan Tabel 5, penggunaan wisata Air Terjun Wiyono dimanfaatkan setiap hari selama satu tahun sehingga jumlah hari dalam satu tahun yang dimanfaatkan untuk melakukan aktivitas adalah 330 hari. Terdapat bulan tertentu lokasi tersebut tidak dikunjungi oleh wisatawan yaitu pada bulan Juni. Hal ini dikarenakan bulan tersebut merupakan bulan puasa atau ramadan sehingga mengurangi aktivitas wisatawan untuk berwisata.

Jumlah wisatawan Air Terjun Wiyono dalam satu tahun sejumlah 6.050 orang. Kemudian dalam menentukan daya dukung ekologis areal wisata Air Terjun Wiyono digunakan faktor pemulihan sebesar 1.5 untuk piknik dan 1,0 untuk berkemah. Kemudian standar luas yang dibutuhkan wisatawan sebesar 907 feet $^{2}$. Berdasarkan data tersebut diperoleh daya dukung ekologis di kawasan Air Terjun Wiyono, seperti pada Tabel 6.

Tabel 6. Daya dukung ekologis areal wisata di kawasan ekowisata Air Terjun Wiyono.

\begin{tabular}{|c|c|c|c|c|c|c|c|}
\hline \multirow[t]{2}{*}{ No } & \multirow[t]{2}{*}{ Lokasi } & \multirow{2}{*}{$\begin{array}{c}\text { Luas } \\
\text { (ha) }\end{array}$} & \multicolumn{2}{|c|}{$\begin{array}{c}\text { Daya Dukung } \\
\text { Ekologis (orang/hari) }\end{array}$} & \multirow{2}{*}{$\begin{array}{c}\text { Jumlah } \\
\text { Wisatawan } \\
\text { (orang/hari) }\end{array}$} & \multicolumn{2}{|c|}{$\begin{array}{l}\text { Kelebihan wisatawan } \\
\text { (orang/hari) }\end{array}$} \\
\hline & & & Piknik & Kemah & & Piknik & Kemah \\
\hline 1 & $\begin{array}{l}\text { Air Terjun } \\
\text { Atas }\end{array}$ & 0,34 & 206 & 137 & \multirow{2}{*}{18} & $188^{*}$ & $119 *$ \\
\hline 2 & $\begin{array}{l}\text { Air Terjun } \\
\text { Bawah }\end{array}$ & 0,07 & 42 & 28 & & $24 *$ & $10^{*}$ \\
\hline & Total & 0,41 & 248 & 165 & 18 & $212 *$ & $129 *$ \\
\hline
\end{tabular}

Keterangan : (*) : Jumlah wisatawan belum melebihi daya dukung ekologis

Sumber : Data Primer (2016).

Hasil perhitungan pada Tabel 6 menunjukkan bahwa daya dukung ekologis Air Terjun Wiyono untuk aktivitas piknik dan berkemah masing-masing sebesar 248 orang/hari dan 165 orang/hari. Daya dukung ekologis areal wisata Air Terjun Atas dengan luas 0,34 ha sebesar 206 orang untuk piknik dan 137 orang untuk berkemah, sedangkan Air Terjun Bawah dengan luas 0,07 ha sebesar 42 orang untuk piknik dan 28 orang untuk berkemah.

Berdasarkan data tersebut, untuk aktivitas piknik dan berkemah di ekowisata Air Terjun Wiyono belum melebihi batas maksimal dari nilai daya dukung ekologis yaitu 248 orang/hari untuk aktivitas piknik dan 165 orang/hari untuk aktivitas berkemah. Jika dilihat pengunjung aktual saat ini yaitu 18 orang/hari, maka nilai tersebut masih jauh dari nilai daya dukung ekologis sehingga wisatawan perlu ditingkatkan namun tetap memperhatikan kondisi biofisik lingkungan. Apabila dimasa yang akan datang wisatawan melebihi dari batas maksimal nilai daya dukung ekologis maka akan berdampak pada penurunan kualitas wisata dan keseimbangan ekosistem (Lucyanti, 2013).

Berdasarkan pengamatan di lapangan, telah terjadi kerusakan vegetasi di sekitar areal wisata sebagai akibat dari adanya aktivitas piknik dan berkemah sehingga menyebabkan terganggunya habitat satwa sebagai salah satu daya tarik wisata, kerusakan jalan setapak di sepanjang jalur ekowisata menyebabkan jalan berlubang dan licin apabila terkena hujan 
sehingga membahayakan wisatawan, dan vandalisme di lokasi air terjun dan areal wisata seperti pencoretan di bebatuan alam dan fasilitas yang disediakan sehingga mengurangi nilai estetika wisata. Untuk itu, pihak pengelola tidak hanya memperhatikan jumlah wisatawan yang datang ke lokasi tersebut akan tetapi tetap memperhatikan kondisi biofisik lingkungan agar tetap terjaga dan tidak rusak sebagaimana konsep ekowisata yang dikemukakan Orams (1995) yaitu perjalanan ke tempat-tempat tertentu yang relatif tidak terganggu dan tidak tercemar dengan tujuan tertentu yaitu studi atau pendidikan, mengagumi, dan menikmati keindahan alam, serta flora dan fauna yang ada di areal wisata tersebut.

Penurunan kualitas wisata akan menyebabkan penurunan daya tarik wisata, akibatnya akan berpengaruh terhadap penurunan jumlah wisatawan dan pendapat-an dari sektor tersebut (Affandy, 2004). Menurut Libosada (1998), mengungkap-kan bahwa dampak negatif yang ditimbulkan dari adanya kelebihan wisatawan adalah terjadinya erosi dan kerusakan jalan setapak, akumulasi sampah akibat aktivitas dari wisatawan, terjadinya gangguan pada satwa liar, dan vandalisme. Dampak negatif yang ditimbulkan akibat aktivitas wisata yang dilakukan akan mengancam keberadaan jenis flora dan fauna yang ada di kawasan ekowisata Air Terjun Wiyono. Keanekaragaman flora dan fauna di kawasan ekowisata Air Terjun Wiyono yang sudah baik harus dijaga keberadaannya sehingga tidak menyebabkan kerusakan dan hilangnya flora dan fauna tersebut.

\section{Daya Dukung Riil}

Data mengenai daya dukung riil dengan mempertimbangkan faktor-faktor sebagi faktor koreksi yaitu curah hujan, diversitas flora, dan diversitas fauna dapat disajikan sebagai berikut.

Tabel 7. Besar nilai faktor koreksi (Cf) pada tiap variabel kawasan ekowisata Air Terjun Wiyono.

\begin{tabular}{clccc}
\hline No & \multicolumn{1}{c}{ Variabel } & $\mathbf{M t}_{\mathbf{1}}$ & $\mathbf{M t}_{\mathbf{2}}$ & Faktor Koreksi \\
\hline 1 & Diversitas Flora & 0,88 & 1 & $88,00 \%$ \\
2 & Diversitas Fauna & 0,42 & 1 & $42,00 \%$ \\
3 & Curah Hujan & 0,23 & 7 & $3,29 \%$ \\
\hline
\end{tabular}

Sumber : Data Primer (2016).

Tabel 7 menunjukkan bahwa hasil perhitungan diversitas flora dan fauna menggunakan Indeks Diversitas Simpson (IDS) memiliki batas variabel total sebesar 1 dan batas besaran variabel masing-masing sebesar 0,88 dan 0,42. Sedangkan hasil perhitungan curah hujan diperoleh berdasarkan data curah hujan tahun 2009-2014 (Bina Marga, 2015). Terdapat 35 bulan basah dan 37 bulan kering, namun data yang diperoleh hanya selama kurun waktu 6 tahun, sehingga indeks curah hujan yang diperoleh sebesar 0,227 termasuk katagori basah yang kemudian ditetapkan sebagai batas besaran variabel dan batas total variabel sebesar 7 (nilai indeks tertinggi dalam klasifikasi Schmidt-ferguson).

Tabel 8. Daya dukung riil kawasan ekowisata Air Terjun Wiyono.

\begin{tabular}{|c|c|c|c|c|c|c|c|}
\hline \multirow{3}{*}{ Lokasi } & \multicolumn{3}{|c|}{ Nilai $\mathbf{C f}_{\mathbf{n}}$} & \multirow{2}{*}{\multicolumn{2}{|c|}{$\begin{array}{l}\text { Nilai PCC } \\
\text { (orang/hari) }\end{array}$}} & \multirow{2}{*}{\multicolumn{2}{|c|}{$\begin{array}{l}\text { Nilai RCC } \\
\text { (orang/hari) }\end{array}$}} \\
\hline & \multirow{2}{*}{$\mathbf{C f _ { 1 }}$} & \multirow{2}{*}{$\mathbf{C f}_{2}$} & \multirow{2}{*}{$\mathbf{C f}_{3}$} & & & & \\
\hline & & & & Piknik & Kemah & Piknik & Kemah \\
\hline Air Terjun Atas & 0,9671 & 0,12 & 0,58 & 630 & 102 & 42 & 7 \\
\hline Air Terjun Bawah & 0,9671 & 0,12 & 0,58 & 129 & 20 & 9 & 2 \\
\hline & Total & & & 759 & 122 & 51 & 9 \\
\hline
\end{tabular}

Sumber : Data Primer (2016). 
Hasil perhitungan nilai RCC seperti pada Tabel 8 di atas menunjukkan jumlah maksimum wisatawan yang dapat mengunjungi kawasan ekowisata Air Terjun Wiyono dengan mempertimbangkan faktor biofisik lingkungan. Kondisi biofisik yang cukup membatasi jumlah wisatawan adalah faktor koreksi curah hujan $\left(\mathrm{Cf}_{1}\right)$, keanekaragaman flora $\left(\mathrm{Cf}_{2}\right)$, dan fauna $\left(\mathrm{Cf}_{3}\right)$.

Daya dukung riil untuk aktivitas piknik di Air Terjun Wiyono sebesar 51 orang/hari atau 357 orang/minggu, sehingga estimasi jumlah kunjungan per bulan yang dapat diterima sebanyak 1428 orang/bulan atau 15708 orang/tahun. Kemudian daya dukung riil untuk aktivitas berkemah di kawasan ekowisata Air Terjun Wiyono sebesar 9 orang/hari atau 63 orang/minggu, sehingga estimasi jumlah kunjungan per bulan yang dapat diterima sebanyak 252 orang/bulan atau 2772 orang/tahun.

Berdasarkan kedua aktivitas wisata tersebut yaitu aktivitas piknik dan berkemah, jika dilihat dari rata-rata banyaknya wisatawan pada tahun 2015 yaitu 18 kunjungan per hari atau 550 kunjungan per bulan atau 6.050 kunjungan per tahun. Maka dari angka tersebut dapat diketahui bahwa kawasan ekowisata Air Terjun Wiyono untuk aktivitas piknik, nilai tersebut masih berada diatas jumlah pengunjung aktual saat ini sehingga jumlah pengunjung masih dapat dioptimalkan sampai dengan 61,48 \%. Sedangkan untuk aktivitas berkemah, kawasan ekowisata Air Terjun Wiyono telah melampaui daya dukung riilnya. Jumlah wisatawan yang datang telah melebihi kapasitas daya tampung sehingga berdampak pada berkurangnya kenyamanan wisatawan dan tergganggunya kondisi satwa yaitu vegetasi yang ada di kawasan tersebut (Lucyanti, 2013). Oleh karena itu, pihak pengelola sudah seharusnya membatasi wisatawan yang datang untuk melakukan aktivitas berkemah di kawasan Air Terjun Wiyono agar tidak merusak kondisi biofisik lingkungan.

\section{Keanekaragaman flora}

Hasil inventarisasi keanekaragaman flora dengan menggunakan metode kuadran di sepanjang jalur ekowisata Air Terjun Wiyono ditemukan jenis pohon sebanyak 28 spesies. Mengacu pada tabel kriteria yang dikemukakan oleh Fandeli (2000), bahwa keanekaragaman jenis pohon di kawasan ekowisata Air Terjun Wiyono masuk dalam kategori baik untuk dijadikan obek ekowisata. Hal ini dikarenakan kawasan ekowisata Air Terjun Wiyono masih memiliki berbagai jenis pohon yang perlu dijaga dan dilestarikan keberadaannya mengingat kawasan tersebut merupakan kawasan konservasi, sehingga menjadikan kawasan tersebut memiliki keanekaragaman flora yang cukup tinggi. Sesuai yang dikemukakan oleh Fandeli (2000) bahwa semakin tinggi jumlah jenis pada suatu kawasan, maka semakin baik kualitas keanekaragamannya.

Kawasan ekowisata Air Terjun Wiyono memiliki berbagai jenis flora yang memiliki daya tarik tersendiri sebagai tujuan wisata. Kawasan tersebut memiliki berbagai jenis pohon kehutanan seperti trembesi (Samanea saman), cempaka (Michelia champaca), waru (Hibiscus tiliaceus), suren (Toona sureni), mindi (Melia azedarach), kedawung (Parkia roxburghii). Pohon tersebut berfungsi sebagai penyimpan air, menahan erosi dan longsor, serta sebagai habitat satwa liar yang ada di kawasan tersebut. Selain itu terdapat beberapa jenis tanaman buah yang mendominasi seperti alpukat (Persea americana), durian (Durio zibethinus), nangka (Artocarpus heterophyllus), kemiri (Aleurites molluccanus), petai (Parkia speciosa), jambu-jambuan (Syzygium aqueum), asam jawa (Tamarindus indica), dan duku (Lansium domesticum). Masyarakat memanfaatkan buah dari pohon tersebut untuk dikonsumsi sebagai kebutuhan sehari-hari dan dapat meningkatkan perekonomian masyarakat.

Keanekaragaman jenis pohon menjadikan salah satu daya tarik tersendiri yang mampu memberikan kontribusi dalam hal pengembangan kawasan di ekowisata Air Terjun Wiyono sebagai tujuan wisata. Adanya keanekaragaman tersebut akan menarik minat wisatawan untuk mendapatkan pengalaman yang berkesan. Sebagaimana yang diungkapkan oleh 
Fandeli (2000), bahwa penggunaan estetika untuk keanekaragaman flora memberikan nilai terhadap masyarakat sekitar untuk melihat, mendengar, menyentuh, dan menikmati pemandangan alam. Nilai estetika tersebut meliputi wisata alam, fotografi, pembuatan film, dan aktivitas lain yang dapat menghasilkan pendapatan ekonomi. Berbagai jenis flora yang terdapat pada setiap jalur pengamatan merupakan hal yang menarik bagi wisatawan karena dapat menambah pengetahuan untuk mengenal dan belajar lebih banyak tentang tipe vegetasi yang ada dan dapat menjadikan sesuatu yang baru bagi para wisatawan. Adanya keanekaragaman flora yang cukup tinggi ini mampu menarik minat wisatawan baik untuk berkunjung serta memperoleh pengalaman baru yang unik dan berbeda dengan obyek daya tarik ekowisata pada daerah lainnya.

\section{Keanekaragaman fauna}

Komposisi jenis vegetasi yang khas pada kawasan ekowisata Air Terjun Wiyono merupakan habitat untuk jenis-jenis satwa tertentu. Interaksi dapat terjadi antara jenis vegetasi dengan jenis satwa yang menempati habitat tersebut maupun antar jenis satwa yang ada (Yosevita, 2013). Hasil inventarisasi fauna yang dilakukan di sepanjang jalur wisata dengan pengamatan langsung di lapangan dan hasil wawancara dengan masyarakat sekitar Air Terjun Wiyono ditemukan jenis fauna sebanyak 23 spesies. Mengacu pada tabel kriteria yang kemukakan oleh Fandeli (2000), bahwa kawasan ekowisata Air Terjun Wiyono masuk kedalam kategori sangat baik untuk dijadikan obyek ekowisata.

Kawasan ekowisata Air Terjun Wiyono mempunyai nilai kompetitif yang tinggi. Terdapat beberapa macam satwa yang dilindungi menurut Peraturan Pemerintah Republik Indonesia Nomor 7 Tahun 1999 seperti rangkong badak (Buceros rhinoceros ), elang ular bido (Spilornis cheela), elang bondol (Haliastur indus ), cekakak belukar (Halcyon smyrnensis). Pengembangan ekowisata Air Terjun Wiyono harus memperhatikan kelestarian dan keberadaan hewan tersebut dengan melihat kriteria yang ada, sehingga dapat memberikan nilai yang dapat mendukung kegiatan pengelolaan ekowisata dengan mempertimbangkan konservasi keanekaragaman hayati setempat. Untuk itu dalam pengembangan atraksi perilaku satwa, ekowisata yang akan dikembangkan tidak diperkenankan merubah perilaku satwa tersebut.

\section{Persepsi wisatawan}

Persepsi wisatawan terhadap pengelolaan ekowisata Air Terjun Wiyono penting dilakukan karena memberikan kemudahan bagi pengelola untuk mengembangkan kawasan ekowisata Air Terjun Wiyono. Berdasarkan hasil wawancara didapatkan persepsi wisatawan terhadap pengelolaan ekowisata Air Terjun Wiyono yang ditunjukkan pada Tabel 9 sebagai berikut.

Tabel 9. Persepsi wisatawan terhadap pengelolaan ekowisata Air Terjun Wiyono.

\begin{tabular}{clcccc}
\hline \multirow{2}{*}{ No } & \multicolumn{1}{c}{ Uraian } & \multicolumn{3}{c}{ Kriteria } \\
\cline { 3 - 6 } & \multicolumn{1}{c}{ Jumlah } & Ya (\%) & Jumlah & Tidak (\%) \\
\hline \multirow{2}{*}{1} & $\begin{array}{l}\text { Mendukung dilakukannya kegiatan } \\
\text { ekowisata }\end{array}$ & 44 & 100 & - & - \\
2 & Memperoleh kepuasan di kawasan & 40 & 90,91 & 4 & 9,09 \\
3 & tersebut & 17 & 38,64 & 27 & 61,36 \\
\hline
\end{tabular}

Sumber : Data Primer (2016).

Berdasarkan Tabel 9 menunjukkan bahwa wisatawan sepenuhnya mendukung untuk dilakukannya kegiatan ekowisata (100\%). Hal ini dikarenakan kegiatan tersebut positif untuk pengembangan ekowisata untuk meningkatkan perekonomian setempat. Pengembangan 
ekowisata dilakukan secara intensif perlu dilakukan dengan tujuan peningkatan data tarik dan meningkatkan perekonomian setempat (Anisaldi, 2014). Selanjutnya, wisatawan yang berkunjung di kawasan ekowisata Air Terjun Wiyono memperoleh kepuasan di kawasan tersebut sebesar 90,91\%, sedangkan pengunjung yang tidak memperoleh kepuasan sebesar $9,09 \%$. Berdasarkan wawancara terhadap wisatawan, kepuasan yang dimaksud adalah wisatawan dapat melihat pemandangan alam yang indah di sekitar lokasi perkemahan dengan kondisi hutan yang masih baik dan interaksi antar wisatawan dari berbagai daerah memberikan kepuasan tersendiri bagi wisatawan.

Persepsi wisatawan mengenai fasilitas yang ada sebanyak 38,64 \% menyatakan memadai dan sebanyak $61,36 \%$ menyatakan tidak memadai. Fasilitas yang ada di kawasan ekowisata Air Terjun Wiyono meliputi toilet dan mushola dengan kondisi yang tidak terawat. Fasilitas yang ada di kawasan ekowisata Air Terjun Wiyono menjadi faktor penting dalam pengelolaan ekowisata karena dapat memberikan kenyamanan dan kepuasan bagi wisatawan untuk berkunjung di kawasan tersebut. Menurut Sulistiyana (2015), mengungkapkan bahwa fasilitas yang lengkap dan masih terawat sebagai pemenuhan kebutuhan atau akomodir wisata akan memberikan kenyamanan kepada wisatawan yang berimbas pada terciptanya kepuasan wisatawan.

\section{Persepsi masyarakat lokal}

Berdasarkan wawancara terhadap masyarakat lokal di kawasan ekowisata Air Terjun Wiyono, maka dapat diketahui tanggapan mereka terhadap pengembangan ekowisata Air Terjun, seperti pada Tabel 10 sebagai berikut.

Tabel 10. Tanggapan masyarakat lokal tentang kawasan ekowisata Air Terjun Wiyono.

\begin{tabular}{|c|c|c|c|c|c|}
\hline \multirow[b]{2}{*}{ No. } & \multirow[b]{2}{*}{ Uraian } & \multicolumn{4}{|c|}{ Kriteria } \\
\hline & & Jumlah & Ya $(\%)$ & Jumlah & Tidak (\%) \\
\hline 1 & Mengetahui arti ekowisata & 33 & 75 & 11 & 25 \\
\hline 2 & $\begin{array}{l}\text { Tahu jenis-jenis flora di sekitar kawasan } \\
\text { Ekowisata }\end{array}$ & 38 & 86,36 & 6 & 13,64 \\
\hline 3 & $\begin{array}{l}\text { Tahu jenis-jenis fauna di sekitar kawasan } \\
\text { Ekowisata }\end{array}$ & 38 & 86,36 & 6 & 13,64 \\
\hline 4 & Tahu manfaat Air Terjun & 31 & 70,45 & 13 & 29,55 \\
\hline 5 & Mendukung seni budaya setempat & 35 & 79,55 & 11 & 20,45 \\
\hline 6 & Mendukung kegiatan ekowisata & 44 & 100 & 0 & 0 \\
\hline 7 & $\begin{array}{l}\text { Mendukung dilakukannya pengembangan } \\
\text { ekowisata }\end{array}$ & 44 & 100 & 0 & 0 \\
\hline 8 & $\begin{array}{l}\text { Membawa pengaruh dengan kondisi yang } \\
\text { ada sekarang }\end{array}$ & 30 & 68,18 & 14 & 31,82 \\
\hline 9 & Peningkatan pendapatan masyarakat & 30 & 68,18 & 14 & 31,82 \\
\hline 10 & Tambahan daya tarik di lokasi kawasan & 38 & 86,36 & 6 & 13,64 \\
\hline
\end{tabular}

Sumber : Data Primer (2016).

Berdasarkan Tabel 10 menunjukkan bahwa masyarakat yang mengetahui ekowisata sebanyak 33 responden (75\%) dan tidak mengetahui ekowisata sebanyak 11 responden (25\%). Pengetahuan tentang ekowisata harus dipahami oleh setiap individu masyarakat. Hal ini dikarenakan daerah tersebut merupakan daerah yang berdekatan langsung dengan kawasan ekowisata Air Terjun Wiyono. Lebih lanjut, Rusita dkk. (2015) menerangkan bahwa pengetahuan tentang ekowisata dilakukan dengan maksud menambah wawasan masyarakat dan menyadarkan masyarakat tentang pentingnya ekowisata. Kemudian masyarakat yang mengetahui tentang jenis flora dan fauna yang ada di kawasan ekowisata Air Terjun Wiyono 
yaitu sebanyak 38 responden $(86,36 \%)$ dan tidak mengetahui sebanyak 6 responden $(13,64 \%)$. Masyarakat yang mengetahui manfaat Air Terjun Wiyono sebanyak 31 responden $(70,45 \%)$ dan tidak mengetahui sebanyak 13 responden $(29,55 \%)$.

Dukungan masyarakat lokal dalam pengembangan ekowisata sangatlah penting meliputi dukungan terhadap seni budaya setempat untuk dikembangkan sebagai daya tarik wisata. Masyarakat yang setuju dikembangkannya kesenian setempat sebagai daya tarik wisata sebanyak 35 responden $(79,55 \%)$ dan tidak setuju sebanyak 11 responden $(20,45 \%)$.

Dukungan selanjutnya yaitu dukungan masyarakat terhadap kegiatan dan pengembangan ekowisata di kawasan ekowisata Air Terjun Wiyono dimana masyarakat mendukung kegiatan ekowisata sebanyak 44 responden (100\%). Hal ini dikarenakan kegiatan tersebut positif akan membawa pengaruh kepada masyarakat lokal dan membuat kawasan ekowisata tersebut menjadi lebih menarik sehingga banyak wisatawan yang datang dan berdampak pada peningkatkan perekonomian masyarakat. Pengembangan kawasan ekowisata yang terencana dan menyeluruh dapat memperoleh manfaat yang optimal untuk masyarakat (Zega, 2014). Kondisi ini juga terjadi pada masyarakat Desa Sumber Agung di Tahura WAR Provinsi Lampung yang telah mempunyai Kelompok Sadar Wisata (POKDARWIS) sebagai salah satu bentuk dukungan masyarakat dalam mengembangkan ekowisata di daerah tersebut (Rusita dkk., 2015). Kemudian, masyarakat yakin bahwa pengembangan ekowisata di kawasan ekowisata Air Terjun Wiyono akan membawa pengaruh dengan kondisi yang ada sekarang dan meningkatkan pendapatan masyarakat sebanyak 30 responden $(68,18 \%)$ dan tidak yakin sebanyak 14 responden $(31,82 \%)$.

Hasil wawancara kepada masyarakat lokal didapatkan bahwa masyarakat yang setuju adanya penambahan daya tarik wisata sebanyak 38 responden $(86,36 \%)$ dan tidak setuju sebanyak 6 responden $(13,46 \%)$. Penambahan daya tarik tersebut meliputi fasilitas umum dan perbanyakan atau budidaya jenis tumbuhan. Fasilitas umum tersebut meliputi pusat informasi, papan informasi, shelter, tempat ibadah, dan toilet. Pelibatan masyarakat di kawasan ekowisata Air Terjun Wiyono disajikan pada Tabel 11.

Tabel 11. Pelibatan masyarakat di kawasan ekowisata Air Terjun Wiyono.

\begin{tabular}{lcc}
\hline \multicolumn{1}{c}{ Karakteristik } & Jumlah Responden & Skor Rata-rata (\%) \\
\hline Setuju & 24 & 54,55 \\
Tidak setuju & 20 & 45,45 \\
\hline
\end{tabular}

Sumber : Data Primer (2016).

Berdasarkan Tabel 11 menunjukkan keinginan masyarakat untuk dilibatkan dalam pengembangan ekowisata di kawasan ekowisata Air Terjun Wiyono. Masyarakat yang setuju untuk dilibatkan sebanyak 24 responden $(54,55 \%)$ dan masyarakat yang tidak setuju dilibatkan sebanyak 20 responden $(45,45 \%)$. Masyarakat yang setuju untuk dilibatkan dalam pengembangan ekowisata Air Terjun Wiyono merupakan responden laki-laki sedangkan masyarakat yang tidak ingin dilibatkan merupakan responden perempuan. Berdasarkan hal tersebut, perbedaan gender menjadi faktor yang mempengaruhi aktivitas seseorang dimana seorang laki-laki lebih kuat secara fisik dibandingkan perempuan. Sebagaimana yang diungkapkan oleh Kusumawati (2007), bahwa aktivitas laki-laki lebih besar dan kuat fisiknya dibandingkan perempuan. Pemanfaatan potensi alam dan lingkungan serta pelibatan masyarakat sekitar pada kawasan konservasi sejalan dengan tujuan pengembangan ekowisatata yaitu konservasi keanekaragaman hayati dan pemberdayaan masyarakat lokal (Sari, 2015). Masyarakat ingin dilibatkan dalam berbagai kegiatan seperti penanaman jenis pohon, pemandu wisata, pemeliharaan, pengelolaan wisata atau hal-hal lainnya yang dapat meningkatkan pendapatan ekonomi masyarakat. 


\section{SIMPULAN}

Simpulan yang didapatkan dalam penelitian yaitu sebagai berikut.

1. Daya dukung areal wisata Air Terjun Wiyono meliputi daya dukung fisik untuk aktivitas piknik dan berkemah masing-masing sebesar 759 orang/hari dan 122 orang/hari. Nilai tersebut belum melebihi daya dukung fisik sehingga wisatawan masih dapat merasakan kenyamanan dan kepuasan berwisata. Daya dukung ekologis untuk aktivitas piknik dan berkemah masing-masing sebesar 248 orang/hari dan 165 orang/hari. Sedangkan, daya dukung riil untuk aktivitas piknik sebesar 51 orang/hari atau 357 orang/minggu atau 1428 orang/bulan atau 15708 orang/tahun dan untuk aktivitas berkemah sebesar 9 orang/hari atau 63 orang/minggu atau 252 orang/bulan atau 396 orang/tahun. Jika dilihat dari rata-rata nilai aktual jumlah pengunjung pada tahun 2015 yaitu 550 orang /bulan atau 6.050 orang/tahun. Maka dari angka tersebut dapat diketahui bahwa kawasan ekowisata Air Terjun Wiyono untuk aktivitas piknik, nilai tersebut masih berada diatas jumlah pengunjung aktual saat ini sehingga masih dapat dioptimalkan sampai dengan 61,48 \%. Sedangkan untuk aktivitas berkemah, kawasan ekowisata Air Terjun Wiyono telah melampaui daya dukung riilnya.

2. Keanekaragaman flora di sepanjang jalur ekowisata masuk dalam katagori baik dengan jumlah 28 spesies dan keanekaragaman fauna masuk dalam katagori sangat baik dengan jumlah 23 spesies.

3. Persepsi wisatawan dan masyarakat sebanyak 44 responden (100\%) mendukung terhadap pengembangan ekowisata Air Terjun Wiyono.

\section{DAFTAR PUSTAKA}

Affandy, W. 2004. Studi daya dukung pengelolaan pariwisata Air Terjun Wiyono Taman Hutan Raya Wan Abdul Rachman Provinsi Lampung. Skripsi. Universitas Lampung. Bandar Lampung. $74 \mathrm{p}$.

Cifuentes, M. 1992. The Technical Report. Buku. Turrialba. Costa Rica. 194 p.

Direktorat Pemberdayaan Masyarakat dan Desa. 2014. Daftar Isian Potensi Desa dan

Kelurahan. Laporan Akhir. Jakarta:Kementrian Dalam Negeri. 84 p.

Douglass, R.W. 1975. Forest Recreation. Buku. Pergamon Press. New York. 336 p.

Fandeli, C. 2000. Perencanaan Kepariwisataan Alam. Buku. Fakultas Kehutanan UGM.

Yogyakarta. 268 p.

Kementerian Kehutanan. 2012. Kumpulan Peraturan Perundang-Undangan di Bidang

Kehutanan dan Konservasi Sumber Daya Alam Hayati dan Ekosistemnya: Undang-

Undang Nomor 5 tahun 1990 tentang Konservasi Sumberdaya Alam Hayati dan

Ekosistemnya. Buku. Dirjen PHKA BKSDA Lampung. Lampung.161-185 p.

Kementerian Kehutanan. 2012. Kumpulan Peraturan Perundang-Undangan di Bidang

Kehutanan dan Konservasi Sumber Daya Alam Hayati dan Ekosistemnya: Undang-

Undang Nomor 7 tahun 1999 tentang Pengawetan Jenis Tumbuhan dan Satwa. Buku.

Dirjen PHKA BKSDA Lampung. Lampung. 305-325 p.

Kusumawati. 2007. Kepemimpinan dalam perspektif gender: adakah perbedaan?. Jurnal Administrasi Bisnis. 1(1):37-40 p.

Libosada, C. 1998. Ecotourism in the Philippines. Buku. Amazon Press. Makati City. 203 p.

Lucyanti, S. 2013. Penilaian daya dukung wisata di Obyek Wisata Bumi Perkemahan

Palutungan Taman Nasional Gunung Ciremai Provinsi Jawa Barat. Prosiding Seminar Nasional Pengelolaan Sumberdaya Alam dan Lingkungan. 232-240 p. 
Pitana, I.G. dan Diarta, I.K.S. 2009. Pengantar Ilmu Pariwisata. Buku. ANDI Press. Yogyakarta. $226 \mathrm{p}$.

Rusita., C. Wulandari., A. Bintoro., P. Budiono., Suprapto., A.Y. Hastuti, dan Y. Susanti. 2015. Pendampingan kelompok agroekowisata Gunung Betung di Taman Hutan Raya Wan Abdul Rachman Provinsi Lampung. Prosiding Seminar Nasional Pengabdian kepada Masyarakat. 139-147 p.

Sari, I. R. 2015. Partisipasi masyarakat dalam pengembangan ekowisata seloringgit di Dusun Mendiro Desa Panglungan Kecamatan Wonosalam. Jurnal Swara Bumi. 2(3): $42-50 \mathrm{p}$.

Sevilla, C. 2007. Research Methods. Buku. Rex Printing Company. Kota Quezon. 217 p. Sulistiyana, R.T. 2015. Pengaruh fasilitas dan harga terhadap kepuasan konsumen (studi pada Museum Satwa). Jurnal Administrasi Bisnis. 25(1):1—9 p.

Sustri. 2009. Daya dukung wisata alam di Taman Nasional Kepulauan Togean Sulawesi Tengah. Tesis. Universitas Gajah Mada. Yogyakarta. 148 p.

Yosevita, T. 2013. Analisis potensi keanekaragaman hayati di Taman Nasional Manusela sebagai daya tarik ekowisata. Jurnal Agroforestri . 8(4): 249-260 p.

Zega, T. F. 2014. Strategi pengembangan kawasan pariwisata Kabupaten Nias Utara. Jurnal Ekonom. 17(4): 204-212 p. 